\title{
Implementasi Metode CHAID (Chi-Squared Automatic Interaction Detection) pada Segmentasi Trend Penjualan Minuman Ringan di Indonesia
}

\author{
Via Sulviana*, Aji Hamim Wigena*, Indahwati* \\ *Departemen Statistika Institut Pertanian Bogor
}

\begin{abstract}
Abstrak-Saat ini beberapa outlet mengevaluasi produknya dengan melihat trend penjualan selama periode tertentu untuk menyusun strategi pemasaran yang efektif. Metode CHAID (Chi-Squared Automatic Interaction Detection) merupakan salah satu metode statistika non-parametrik yang efisien untuk melakukan pengklasifikasian terhadap aspek-aspek apa saja yang dapat meningkatkan penjualan minuman ringan tersebut. CHAID memilih peubah-peubah yang signifikan berdasarkan uji Khi-Kuadrat antara kategori-kategori peubah penjelas dengan kategori-kategori peubah respon berskala nominal atau ordinal. Hasil dari CHAID berupa diagram pohon berdasarkan segmen dari peubah penjelas yang berasosiasi terhadap peubah respon menjadi informasi yang lebih mudah dimengerti. Penelitian ini menghasilkan 11 dari 20 segmen yang dijadikan sebagai acuan dalam menentukan target pasar terhadap peningkatan trend penjualan minuman ringan yang tersebar di kota-kota besar di Indonesia. Segmen yang terbentuk berasal dari 4 peubah penjelas yaitu persebaran kota, tipe outlet, sumber pembelian, dan metode pembayaran dengan akurasi segmentasi sebesar $\mathbf{7 1 . 4 \%}$.

Kata kunci-CHAID; klasifikasi; segmentasi; trend penjualan minuman ringan;
\end{abstract}

\section{PENDAHULUAN}

\section{A. Latar Belakang}

Demografi Indonesia sebagai negara dengan lebih dari 250 juta konsumen memberikan potensi besar bagi pertumbuhan pasar minuman ringan di Indonesia. Beragam jenis minuman ringan yang tersedia di Indonesia di antaranya Air Minum Dalam Kemasan (AMDK), minuman susu beraneka rasa, minuman isotonik, minuman kopi/teh siap saji, minuman sari buah, sampai minuman berkarbonasi. Adapun semakin beragam pilihan jenis minuman ringan yang ada menyebabkan terjadinya persaingan pasar.

Segmentasi merupakan salah satu strategi pemasaran untuk mengelompokkan pasar yang hetero- gen ke dalam segmen-segmen pasar yang lebih kecil dan homogen. Salah satu strategi pemasaran agar outlet minuman ringan memperoleh keuntungan adalah dengan mengetahui trend penjualan setiap produk yang dijualnya sebagai bahan pertimbangan terhadap produk apa saja yang membuat pelaku usaha mampu bertahan.

Penciri karakteristik trend penjualan suatu outlet terhadap berbagai jenis minuman ringan dapat dilakukan dengan menggunakan metode CHAID. Metode CHAID merupakan metode eksplorasi untuk mendeteksi adanya hubungan antara peubah respon dengan peubah penjelas serta interaksi antar peubah penjelas secara otomatis. Implementasi CHAID telah banyak digunakan dalam penelitian sebelumnya dalam bidang segmentasi pasar, misalnya metode CHAID digunakan untuk menganalisis segmentasi pasar pada pengguna handphone Samsung dalam lingkup mahasiswa IPB Santoso (2017). Penelitian ini mengklasifikasikan karakteristik yang mampu meningkatkan trend penjualan berbagai jenis minuman ringan berdasarkan persebaran di kota besar Indonesia. Berdasarkan klasifikasi tersebut diharapkan outlet-outlet minuman ringan yang tersebar di sembilan kota besar Indonesia tersebut mampu meningkatkan penjualan dan memaksimumkan keuntungan.

\section{B. Tujuan}

Tujuan penelitian ini adalah mengklasifikasikan karakteristik yang menjadi penciri keragaman trend penjualan minuman ringan dan menentukan target pasar berdasarkan hasil segmentasi di sembilan kota besar Indonesia dengan menggunakan metode CHAID. 
Implementasi Metode CHAID (Chi-Squared Automatic Interaction Detection) pada Segmentasi Trend Penjualan Minuman Ringan di Indonesia

Xplore, Vol 2(2):24-31 25

\section{TINJAUAN PUSTAKA}

\section{A. Klasifikasi}

Klasifikasi merupakan proses menemukan model berupa pohon keputusan dengan maksud untuk mendapatkan perkiraan suatu objek yang belum diketahui labelnya Agresti (1990). Pohon klasifikasi merupakan metode statistika yang digunakan untuk memperkirakan sampel dalam kelas-kelas peubah respon. Pohon klasifikasi yang dibentuk berasal dari hasil penyekatan data secara berulang, dimana kelas dan nilai peubah penjelas dari setiap sampel pada data sudah diketahui. Setiap sekatan data dinyatakan sebagai node (simpul) pada pohon keputusan yang terbentuk.

Menurut Schowengerdt (2012) klasifikasi dibedakan menjadi dua kelompok, yaitu non parametrik dan parametrik. Adapun kelompok parametrik antara lain regresi logistik dan diskriminan yang memerlukan asumsi. Sedangkan kelompok non parametrik antara lain CHAID, CART, Exhaustive CHAID, dan lain-lain yang tidak memerlukan asumsi.

\section{B. Metode CHAID}

Menurut Alamudi et al. (1998) metode CHAID merupakan metode yang cukup efisien untuk menjelaskan keterkaitan struktural dalam suatu data. Sedangkan menurut Kunto and Hasana (2006), CHAID digunakan untuk membentuk segmentasi yang membagi sebuah sampel menjadi dua atau lebih kelompok yang berbeda berdasarkan sebuah kriteria tertentu.

Adapun algoritma CHAID secara umum terdiri dari 3 tahapan yaitu sebagai berikut :

1) Penggabungan (Merging)

Tahap penggabungan untuk tiap peubah penjelas dalam menggabungkan kategori yang tidak signifikan adalah:

a) Pembentukan tabel kontingensi dua arah untuk setiap kategori peubah penjelas terhadap kategori peubah responnya.

b) Uji Khi-Kuadrat $\left(\chi^{2}\right)$ setiap pasang kategori pada peubah penjelas yang dapat dipilih menjadi satu, untuk menguji kebebasannya dalam sub tabel kontingensi 2 x J kategori yang dibentuk oleh sepasang kategori tersebut den- gan peubah respon. Langkah-langkah uji Khi-Kuadrat adalah sebagai berikut :

i) Menuliskan hipotesis awal

$\mathrm{HO}$ : tidak ada hubungan antara peubah respon dan peubah penjelas

H1 : ada hubungan antara peubah respon dan peubah penjelas

ii) Menghitung statistik uji Khi-Kuadrat Nilai $\chi^{2}$ setiap pasangan kategori dengan rumus Agresti (1990):

$$
\chi^{2}=\sum_{i-1}^{r} \sum_{j=1}^{c} \frac{\left(n_{i j}-E_{i j}\right)^{2}}{E_{i j}}
$$

dengan

$$
E_{i j}=\frac{n_{i .} n_{. j}}{n}
$$

untuk $\mathrm{i}=1, \ldots, \mathrm{r}$ dan $\mathrm{j}=1, \ldots, \mathrm{c}$ Keterangan:

$E_{i j}$ : nilai harapan pengamatan pada baris ke-i dan kolom ke-j ;

$n_{i j}$ : banyaknya pengamatan pada baris ke-i dan kolom ke-j;

$n_{i}$ : banyaknya pengamatan pada baris ke-i;

$n_{. j}$ : banyaknya pengamatan pada kolom ke-j;

$n$ : banyaknya pengamatan;

iii) Kriteria penolakan

Apabila $\chi_{\text {hitung }}^{2}>\chi_{\text {tabel }}^{2}$ atau $p$-value $<\alpha$ maka tolak H0, sehingga tahapan selanjutnya dapat dilanjutkan ke langkah pemisahan. Sedangkan apabila tidak memenuhi kriteria penolakan dalam arti terdapat kategori yang mempunyai nilai $\chi^{2}$ berpasangan terkecil dengan $p$-value terbesar maka digabungkan menjadi sebuah kategori tunggal dan kemudian dilanjutkan ke langkah c dan d.

c) Apabila terdapat kategori gabungan yang memiliki 3 kategori atau lebih, dilakukan pengujian apakah suatu kategori peubah penjelas seharusnya dipisah atau tidak. Jika didapat nilai Khi-Kuadrat yang signifikan maka pisahkan dengan kategori yang lainya. Jika lebih dari satu kategori untuk dipisah, pemisahan 
dilakukan pada kategori dengan KhiKuadrat tertinggi. Kemudian kembali ke langkah $b$.

d) Penghitungan $p$-value terkoreksi Bonferroni berdasarkan tabel yang telah digabung dengan rumus :

$$
1-(1-\alpha)^{M}>\alpha
$$

Koreksi Bonferroni dilakukan bila tahap penggabungan ada kategori dari peubah penjelas yang digabung. Koreksi Bonferroni untuk tabel yang mengalami pengurangan kategori sesuai dengan tipe peubahnya adalah sebagai berikut: Peubah penjelas nominal

$$
M=\sum_{i=0}^{r-1}(-1)^{i} \frac{(r-1)^{c}}{i !(r-1) !}
$$

Keterangan :

M : pengali Bonferroni

c : banyaknya kategori asal

$\mathrm{r}$ : banyaknya kategori baru

2) Pemisahan (Splitting)

Tahap pemisahan memilih peubah penjelas yang mana yang akan digunakan sebagai yang terbaik. Pemilihan dikerjakan dengan membandingkan $p$-value (dari tahap merging) pada setiap peubah penjelas.

3) Penghentian (Stopping)

Mengulangi langkah penggabungan untuk sub kelompok berikutnya. Tahap stopping dilakukan ketika semua sub kelompok yang telah dianalisis dan juga telah berisi pengamatan dengan jumlah sedikit.

\section{Evaluasi Kinerja Klasifikasi}

Matriks konfusi digunakan untuk mengukur kinerja sistem klasifikasi yang berisi informasi tentang kelas prediksi dan kelas aktual. Menurut Hosmer et al. (2013), ketepatan klasifikasi terdiri atas True Positive dan True Negative, sedangkan kesalahan klasifikasi terdiri atas False Negative dan False Positive. Berikut disajikan tabel matriks konfusi pada Tabel I.

Pada klasifikasi dengan jumlah keluaran kelas yang lebih dari dua (multi-class) cara menghitung
Tabel I

MATRIKS KONFUSI

\begin{tabular}{ccc}
\hline \multirow{2}{*}{ Kelas Aktual } & \multicolumn{2}{c}{ Kelas Prediksi } \\
\cline { 2 - 3 } & Kelas Positif & Kelas Negatif \\
\hline Kelas Positif & TPi & FNi \\
Kelas Negatif & FPi & TNi \\
\hline
\end{tabular}

akurasi dapat dilakukan dengan menghitung ratarata dari nilai akurasi pada tiap kelas seperti formula berikut.

Akurasi $=\sum_{i=1}^{l} \frac{T P_{i}+T N_{i} / T P_{i}+T N_{i}+F P_{i}+F N_{i}}{l} \times 100 \%$

Keterangan :

1) $T P_{i}$ adalah True Positive, yaitu jumlah data positif yang terklasifikasi dengan benar oleh sistem untuk kelas ke-i.

2) $T N_{i}$ adalah True Negative, yaitu jumlah data negatif yang terklasifikasi dengan benar oleh sistem untuk kelas ke-i.

3) $F N_{i}$ adalah False Negative, yaitu jumlah data negatif namun terklasifikasi salah oleh sistem untuk kelas ke-i.

4) $F P_{i}$ adalah False Positive, yaitu jumlah data positif namun terklasifikasi salah oleh sistem untuk kelas ke-i.

5) $l$ adalah jumlah kelas.

\section{METODOLOGI}

\section{A. Data}

Data yang digunakan dalam penelitian ini adalah data sekunder dari hasil survei yang dilakukan oleh PT. Qasa Strategic Consulting pada November hingga Desember 2017. Metode survei yang digunakan adalah penarikan contoh acak berlapis (stratified random sampling) terhadap outlet di Indonesia. Ada sembilan kota yang terpilih dari penentuan sampling antara lain Jakarta, Padang, Makasar, Denpasar, Bandung, Semarang, Surabaya, Medan, dan Banjarmasin. Ada dua jenis stratifikasi outlet yaitu WHS (wholesaler) yaitu agen yang menjual produk secara grosir dan PROV (provision) yaitu 
Implementasi Metode CHAID (Chi-Squared Automatic Interaction Detection)

pada Segmentasi Trend Penjualan Minuman Ringan di Indonesia

Xplore, Vol 2(2):24-31 27

agen yang menjual produk secara eceran. Pada Tabel II disajikan peubah respon dan peubah penjelas.

Tabel II

Daftar Peubah Karakteristik

\begin{tabular}{|c|c|}
\hline Nama Peubah & Kategori \\
\hline \multirow{3}{*}{$\begin{array}{l}\text { Trend Penjualan Minuman Ringan } \\
\text { (Y) }\end{array}$} & 1. Menurun \\
\hline & 2. Stabil \\
\hline & 3. Meningkat \\
\hline \multirow[t]{2}{*}{ Tipe Outlet (X1) } & 1. wholesaler \\
\hline & 2. provision \\
\hline \multirow[t]{5}{*}{ Jenis Minuman (X2) } & 1. Sari buah \\
\hline & 2. Teh \\
\hline & 3. Susu \\
\hline & 4. AMDK \\
\hline & 5. Karbonasi \\
\hline \multirow[t]{6}{*}{ Sumber Pembelian (X3) } & 1. Distributor \\
\hline & 2. Salesman Agen \\
\hline & 3. Sales Pribadi \\
\hline & 4. Pasar \\
\hline & 5. Modern market \\
\hline & 6. Grosir \\
\hline \multirow[t]{2}{*}{ Diskon (X4) } & 0. Tidak Ada \\
\hline & 1. Ada \\
\hline \multirow[t]{9}{*}{ Persebaran Kota (X5) } & 1. Jakarta \\
\hline & 2. Bandung \\
\hline & 3. Semarang \\
\hline & 4. Surabaya \\
\hline & 5. Medan \\
\hline & 6. Padang \\
\hline & 7. Makassar \\
\hline & 8. Denpasar \\
\hline & 9. Banjarmasin \\
\hline \multirow[t]{2}{*}{ Metode Pembayaran (X6) } & 1. Tunai \\
\hline & 2. Kredit \\
\hline
\end{tabular}

\section{B. Prosedur Analisis Data}

Tahapan analisis pada penelitian ini adalah sebagai berikut :

1) Melakukan cleaning data yang dibutuhkan berdasarkan kategori yang ditentukan.

2) Melakukan eksplorasi data terhadap data yang telah diperoleh untuk mengetahui karakteristik responden.

3) Mengidentifikasi peubah penciri dengan menggunakan algoritma CHAID yaitu penggabungan (merging), pemisahan (splitting) dan penghentian (stopping).

4) Menentukan segmentasi trend penjualan berbagai jenis minuman ringan di Indonesia dengan menginterpretasikan diagram pohon CHAID.

5) Menentukan target peningkatan penjualan berbagai jenis minuman ringan di Indonesia yang sudah terbentuk. Penentuan target peningkatan penjualan dilihat dari nilai indeks terbaik pada tabel gain for nodes pada analisis CHAID.

6) Menghitung nilai ketepatan klasifikasi dari rata-rata nilai akurasi tiap kelas yang diperoleh dari evaluasi kinerja klasifikasi.

\section{HASIL DAN PEMBAHASAN}

\section{A. Distribusi Sampel}

Responden pada penelitian ini merupakan outlet yang menjual berbagai jenis minuman ringan sebanyak 5804 responden. Stratifikasi responden terdiri dari 1619 tipe wholesaler dan sebanyak 4185 tipe provision. Persebaran kota pada penelitian ini di dominasi kota Denpasar sebanyak 923 outlet dan Jakarta sebanyak 910 outlet. Hal ini dapat dikatakan bahwa secara umum distribusi sampel berupa outletoutlet minuman ringan paling banyak tersebar di kota Denpasar dan Jakarta dengan penjualan secara eceran.

\section{B. Gambaran Umum Data}

Eksplorasi data dilakukan untuk mengetahui gambaran umum responden berupa outlet yang menjual minuman ringan di sembilan kota besar Indonesia. Berikut Gambar 1 disajikan informasi mengenai trend penjualan minuman ringan menurut persepsi responden. Trend penjualan minuman ringan selama tiga bulan terakhir paling banyak dikategorikan meningkat sebesar $47 \%$ sedangkan paling sedikit dikategorikan menurun sebesar $24 \%$. Hal tersebut dapat dikatakan bahwa secara umum selama tiga bulan terakhir responden secara subjektif mengindikasikan penjualan minuman ringannya mengalami peningkatan.

\section{Deskripsi Data Berdasarkan Karakteristik Responden}

Secara eksplorasi pada Gambar 2 dapat diketahui bahwa berdasarkan tipe outlet yang paling banyak menyatakan mengalami trend meningkat dari 5804 outlet adalah wholesaler sebesar $85.36 \%$, namun 


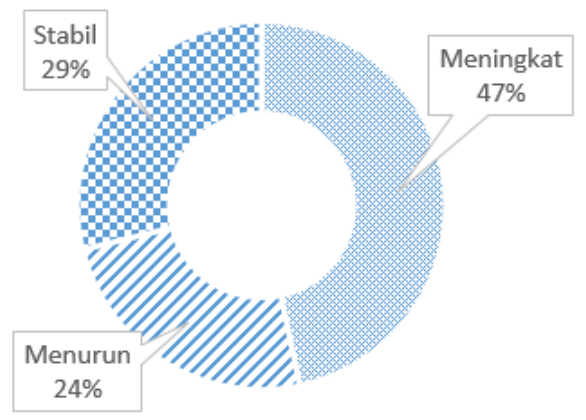

Gambar 1. Trend penjualan minuman ringan selama 3 bulan terakhir

tidak ada tipe wholesaler yang menyatakan trend penjualan minuman ringannya mengalami penurunan. Adapun pada kategori stabil jenis provision dengan jumlah outlet mencapai $34.36 \%$.

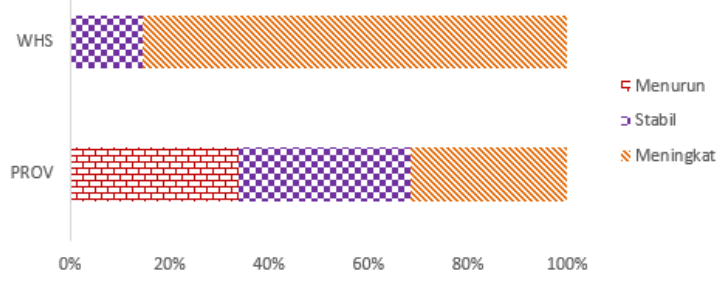

Gambar 2. Trend penjualan minuman ringan berdasarkan tipe outlet

Secara eksplorasi berdasarkan Gambar 3 dapat dilihat bahwa dari 5804 outlet yang berhasil diwawancarai oleh tim surveyor menyatakan outletoutlet minuman ringan yang tersebar di Indonesia paling banyak menyatakan penjualan minuman ringannya mengalami peningkatan berada di kota Banjarmasin dengan persentase mencapai $80.25 \%$, sedangkan kota Medan merupakan kota yang paling sedikit menyatakan peningkatan pada penjualan minuman ringannya dengan persentase $16.84 \%$. Adapun pada kategori stabil kota Surabaya paling banyak sebesar $56.62 \%$ sedangkan kota Denpasar hanya $5.96 \%$ yang menyatakan stabil. Kemudian kota Denpasar merupakan kota yang paling banyak menyatakan penurunan pada penjualan minuman ringannya sebesar $73.35 \%$, sedangkan untuk kota Jakarta dan Banjarmasin tidak ada yang menyatakan mengalami penurunan selama tiga bulan terakhir penjualan.

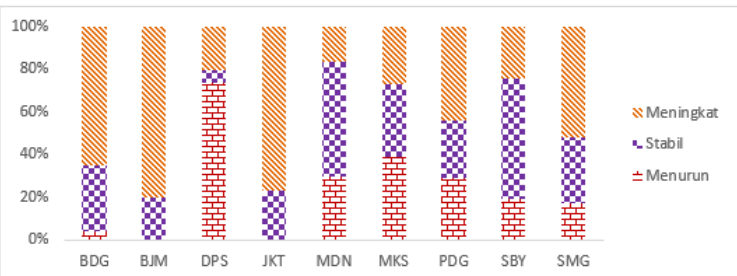

Gambar 3. Trend penjualan minuman ringan berdasarkan persebaran kota

Secara eksplorasi dari 5804 outlet yang berhasil diwawancarai oleh tim surveyor menyatakan jenis minuman ringan yang paling banyak dijual dan memengaruhi peningkatan trend penjualan minuman ringan adalah jenis susu segar sebesar $65.63 \%$. Pada peubah sumber pembelian awal produk yang akan dijual oleh outlet-outlet tersebut nantinya paling banyak menyatakan peningkatan trend penjualan minuman ringannya bersumber dari modern market sebesar $74.07 \%$. Selanjutnya paling banyak outlet menyatakan peningkatan trend penjualan minuman ringannya saat terdapat diskon dari sumber pembelian dengan persentase $62.50 \%$. Sedangkan pada peubah metode pembayaran paling banyak outlet melakukan pembayaran dalam pembelian produk awalnya secara kredit sebesar $88.65 \%$.

\section{Pembentukan Segmentasi pada Analisis CHAID}

Segmentasi yang dihasilkan pada analisis CHAID pada trend penjualan berbagai jenis minuman ringan dengan kategori meningkat, stabil, dan menurun yang tersebar di sembilan kota besar Indonesia dapat dilihat pada Gambar 4 berupa diagram pohon klasifikasi CHAID.

Berdasarkan analisis CHAID ada empat dari enam peubah penjelas yang berasosiasi signifikan dengan peubah responnya, yaitu tipe outlet, persebaran kota, sumber pembelian, dan metode pembayaran, sehingga ada dua peubah penjelas yang dinyatakan tidak mempunyai hubungan dengan peubah respon, yaitu jenis minuman dan diskon. Hal tersebut dapat dikatakan bahwa jenis minuman ringan dan diskon tidak menjadi penciri karakteristik trend penjualan minuman ringan sehingga tidak dapat diklasifikasikan berdasarkan produk yang dijualnya.

Adapun $p$-value dan nilai uji Khi-Kuadrat dari masing-masing peubah penjelas yang dinyatakan mempunyai hubungan dengan peubah responnya di- 


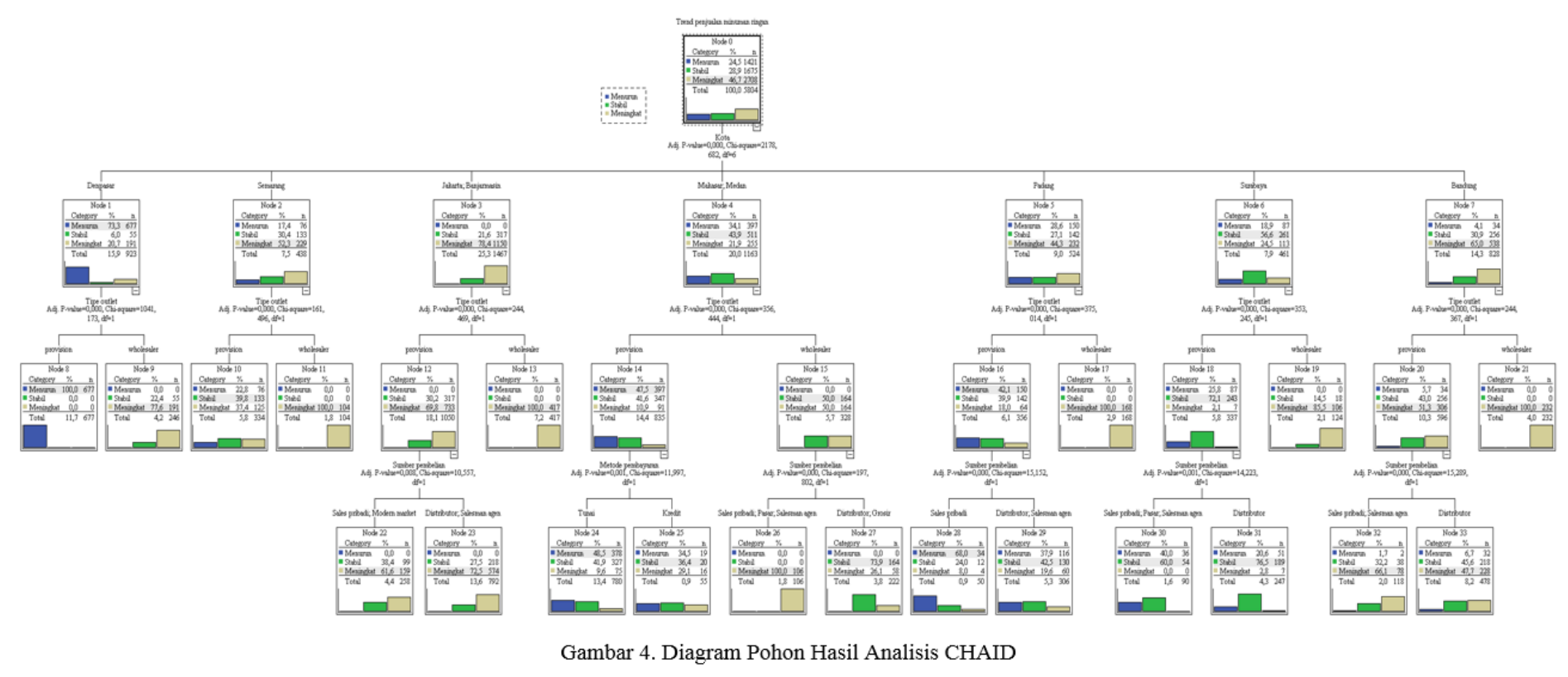

mana dari keempat peubah telah memenuhi kriteria penolakan yaitu kurang dari $\alpha=0.05$ sehingga dapat ditarik kesimpulan bahwa terdapat hubungan signifikan antara keempat peubah tersebut dengan peubah respon yaitu trend penjualan minuman ringan.

Pada hasil dari diagram pohon yang terbentuk melalui analisis CHAID terlihat bahwa peubah persebaran kota merupakan peubah penjelas terbaik yang digunakan untuk membagi peubah responnya yaitu trend penjualan minuman ringan. Kemudian peubah tipe outlet merupakan peubah penjelas yang signifikan untuk membagi kategori pada node ke1 pada peubah persebaran kota. Selanjutnya pada node ke-2 dibagi lagi berdasarkan peubah sumber pembelian dan metode pembayaran yang menjadi terminal akhir dari masing-masing node (simpul).

Pada diagram pohon analisis CHAID yang terbentuk menerangkan bahwa trend penjualan berbagai jenis minuman ringan dibagi menjadi 20 segmen. Adapun interpretasi dari hasil diagram pohon CHAID tiap segmennya sebagai berikut.
1) Segmen 1 yang berakhir pada terminal node ke-8 menunjukkan pada kota Denpasar dengan tipe provision didominasi oleh trend menurun sebesar $100 \%$.

2) Segmen 2 yang berakhir pada terminal node ke-9 menunjukkan pada kota Denpasar dengan tipe wholesaler didominasi oleh trend meningkat sebesar $77.6 \%$.

3) Segmen 3 yang berakhir pada terminal node ke-10 menunjukkan pada kota Semarang dengan tipe provision didominasi oleh trend stabil sebesar $39.8 \%$.

4) Segmen 4 yang berakhir pada terminal node ke-11 menunjukkan pada kota Semarang dengan tipe wholesaler didominasi oleh trend meningkat sebesar $100 \%$

5) Segmen 5 yang berakhir pada terminal node ke-22 menunjukkan pada kota Jakarta dan Banjarmasin dengan tipe provison serta sumber pembelian awal produk bersumber dari sales pribadi dan modern market didominasi oleh trend meningkat sebesar $61.6 \%$.

6) Segmen 6 yang berakhir pada terminal node ke-23 menunjukkan pada kota Jakarta dan Banjarmasin dengan tipe provision serta sumber pembelian awal produk bersumber dari distributor dan salesman agen didominasi trend meningkat sebesar $72.5 \%$.

7) Segmen 7 yang berakhir pada terminal node 
ke-13 menunjukkan pada kota Jakarta dan Banjarmasin dengan tipe wholesaler didominasi trend meningkat sebesar $100 \%$.

8) Segmen 8 yang berakhir pada terminal node ke-24 menunjukkan pada kota Makasar dan Medan dengan tipe provision serta metode pembayaran secara tunai didominasi trend menurun sebesar $48.5 \%$.

9) Segmen 9 yang berakhir pada terminal node ke-25 menunjukkan pada kota Makasar dan Medan dengan tipe provision serta metode pembayarna secara kredit didominasi trend stabil sebesar $36.4 \%$.

10) Segmen 10 yang berakhir pada terminal node ke-26 menunjukkan pada kota Makasar dan Medan dengan tipe wholesaler serta sumber pembelian awal produk bersumber dari sales pribadi, pasar, dan salesman agen didominasi trend meningkat sebesar $100 \%$.

11) Segmen 11 yang berakhir pada terminal node ke-27 menunjukkan pada kota Makasar dan Medan dengan tipe wholesaler serta sumber pembelian awal produk bersumber dari distributor dan grosir didominasi trend stabil sebesar $73.9 \%$.

12) Segmen 12 yang berakhir pada terminal node ke-28 menunjukkan pada kota Padang dengan tipe provision serta sumber pembelian bersumber dari sales pribadi didominasi trend menurun sebesar $68 \%$.

13) Segmen 13 yang berakhir pada terminal node ke-29 menunjukkan pada kota Padang dengan tipe provision serta sumber pembelian awal produk bersumber dari distributor dan salesman agen didominasi trend stabil sebesar $42.5 \%$.

14) Segmen 14 yang berakhir pada terminal node ke-17 menunjukkan pada kota Padang dengan tipe wholesaler didominasi trend meningkat sebesar $100 \%$.

15) Segmen 15 yang berakhir pada terminal node ke-30 menunjukkan pada kota Surabaya dengan tipe provision serta sumber pembelian awal produk bersumber dari sales pribadi, pasar, dan salesman agen didominasi trend stabil sebesar $60 \%$.

16) Segmen 16 yang berakhir pada terminal node ke-31 menunjukkan pada kota Surabaya dengan tipe provision serta sumber pembelian awal produk bersumber dari distributor didominasi trend stabil sebesar $76.5 \%$.

17) Segmen 17 yang berakhir pada terminal node ke-19 menunjukkan pada kota Surabaya dengan tipe wholesaler didominasi trend meningkat sebesar $85.5 \%$.

18) Segmen 18 yang berakhir pada terminal node ke-32 menunjukkan pada kota Bandung dengan tipe provision serta sumber pembelian awal produk bersumber dari sales pribadi dan salesman agen didominasi trend meningkat sebesar $66.3 \%$.

19) Segmen 19 yang berakhir pada terminal node ke-33 menunjukkan pada kota Bandung dengan tipe provision serta sumber pembelian awal produk bersumber dari distributor didominasi trend meningkat sebesar $47.7 \%$.

20) Segmen 20 yang berakhir pada terminal node ke-21 menunjukkan pada kota Bandung dengan tipe wholesaler didominasi trend wholesaler sebesar $100 \%$.

\section{E. Penentuan Target Hasil Analisis CHAID}

Pada kasus ini apabila ingin menentukan trend penjualan minuman ringan yang akan dijadikan acuan untuk evaluasi pertumbuhan penjualan berbagai jenis minuman ringan tersebut, maka akan dipilih segmen-segmen dengan jumlah trend penjualan minuman ringan kategori menurun terkecil serta mempunyai jumlah trend penjualan minuman ringan dengan kategori meningkat terbesar.

Berdasarkan segmentasi pada interpretasi diagram pohon CHAID, akan ditentukan target pasar yang akan dijadikan acuan untuk menentukan peningkatan trend penjualan berbagai jenis minuman ringan pada outlet-outlet yang tersebar di sembilan kota besar Indonesia. Adapun yang dijadikan target pasar untuk menentukan trend penjualan minuman ringan yang meningkat terdapat 11 dari 20 segmen, yaitu segmen ke-7, 20, 14, 10, 4, 17, 2, 6, 18, 5, 19 dimana kesebelas segmen tersebut merupakan segmen yang didomiasi oleh trend penjualan minuman ringan dengan kategori meningkat.

\section{F. Evaluasi Kinerja Klasifikasi}

Pada Tabel III berikut merupakan evaluasi kinerja klasifikasi dapat ditentukan dengan melihat keselu- 
ruhan nilai akurasi yang dihasilkan pada analisis CHAID sebesar $71.4 \%$ dengan risiko kesalahan yang diperkirakan sebesar 28.6\%. Adapun galat baku yang dihasilkan sangat kecil yaitu 0.006 hal ini menyatakan bahwa seluruh sample telah representatif mewakili populasi yang dihasilkan dari hasil analisis CHAID.

Tabel III

KETEPATAN KLASIFIKASI MODEL CHAID

\begin{tabular}{ccccc}
\hline \multirow{2}{*}{ Kelas Aktual } & \multicolumn{3}{c}{ Kelas Prediksi } & Persentase \\
\cline { 2 - 4 } & Menurun & Stabil & Meningkat & Benar \\
\hline Menurun & 1089 & 298 & 34 & $76.6 \%$ \\
Stabil & 339 & 690 & 646 & $41.2 \%$ \\
Meningkat & 79 & 266 & 2363 & $87.3 \%$ \\
Persentase & & & & \\
keseluruhan & $26.0 \%$ & $21.6 \%$ & $52.4 \%$ & $71.4 \%$ \\
\hline
\end{tabular}

\section{SIMPULAN}

Karakteristik-karakteristik yang menjadi penciri keragaman trend penjualan berbagai jenis minuman ringan adalah persebaran kota, tipe outlet, sumber pembelian dan metode pembayaran dengan taraf nyata $10 \%$. Pada metode CHAID menghasilkan 20 segmen pasar untuk meningkatkan trend penjualan minuman ringan dengan ketepatan klasifikasi sebesar $71.4 \%$.

Segmen pasar yang dijadikan target pasar untuk memaksimumkan keuntungan agar trend penjualan minuman ringan selalu mengalami peningkatan dapat dilihat pada segmen ke- 7, 20, 14, 10, 4, 17, 2, 6, 18, 5, 19 dimana peubah yang paling berpengaruh adalah persebaran kota besar di Indonesia.

\section{DAFTAR PUSTAKA}

Agresti, A. (1990). Categorical Data Analysis. USA: University of Florida.

Alamudi, A., A. H. Wigena, and Aunuddin (1998). Eksplorasi struktur data menggunakan metode chaid. Forum Statistika dan Komputasi 3(1), 1016.

Hosmer, J. D. W., S. Lemeshow, and R. X. Strurdivant (2013). Applied logistic regression. John Wiley and Sons 398.
Kunto, Y. S. and S. N. Hasana (2006). Analisis chaid sebagai alat bantu statistika untuk segmentasi pasar (studi kasus pada koperasi syari'ah alhidayah). Jurnal Manajemen Pemasaran 1(2), 88-98.

Santoso, W. A. (2017). Aplikasi metode chaid dalam analisis segmentasi pasar pada pengguna handphone samsung (studi kasus mahasiswa s1 ipb angkatan 53). S1 thesis Institut Pertanian Bogor, 1-37.

Schowengerdt, R. A. (2012). Techniques for image processing and classifications in remote sensing. Academic Press. 